\title{
NOTES
}

\section{Taxable Status of Reimbursement of Items Previously Deducted*}

Cases have frequently arisen where there is involved a reimbursement of a bad debt, loss or expense item or a refund or reduction in the amount of taxes, which has been allowed as a deduction from gross income in a prior year. The problem thus presented is the manner in which this refund or reimbursement or reduction is to be treated. Is it to be included in gross income for the year in which it is received by the taxpayer? Or is the deduction to be disallowed? And what effect does the running of the statute of limitations for making additional assessments have on this problem? The question is an important one and is marked by disagreement in court and Board of Tax Appeals decisions and in rulings of the Treasury Department. The purpose of this discussion is to point out particular problems that not infrequently arise and to attempt to clarify the subject as much as possible.

\section{A. Recovery of a Debt Previously Deducted as Bad}

The Treasury Regulations provide that "any amount subsequently received on account of a bad debt or on account of a bad debt previously charged off and allowed as a deduction for income tax purposes, must be included in gross income for the taxable year in which received". . This rule has been followed with uniformity by both the Board of Tax Appeals and the courts. Thus, the Board has held where the taxpayer in 19r4 charged off the account of a corporation which had been declared bankrupt and in 1923 received money for this by terms of the will of the sole shareholder of the corporation, this recovery constituted income for $1923 .^{2}$ Where taxpayer charged off accounts as worthless in 1916 and in IgI8 collected the amount from debtor, the inclusion of said amount in gross income for 1918 was held proper. ${ }^{3}$ The courts have also adhered to the proposition that any later collection of a debt allowed as a deduction in a previous year as worthless must be returned as income."

When there is recovery of a debt improperly deducted as bad, there is some question as to whether the recovery may be treated as income in the year in which received. In Commissioner v. Liberty Bank Trust Co., ${ }^{5}$ the Circuit Court of Appeals held the amount recovered is chargeable to income for the years in which received, reversing the Board ${ }^{6}$ which had held that the recovery should be accounted for by disallowance of the deduction, on the theory that understatement of income in a previous year should not be made the basis of increasing income in a current year. The Circuit Court of Appeals in its decision 7 declared that the taxpayer was estopped to deny the truth of the statement as to the

* The writer is indebted to Professor Paul W. Bruton for invaluable advice in the preparation of this article. (1936).

I. U. S. Treas. Reg. 94, Art. 23 (k)-I (1936). See also, U. S. Treas. Reg. 94, Art. 42-I

2. Excelsior Printing Co., 16 B. T. A. 886 (1929).

3. Iberville Wholesale Grocery Co., 17 B. T. A. 235 (1929) ; see also, First National Bank of Key West, 26 B. T. A. 370, 378 (I932); Askin \& Marine Co., 26 B. T. A. 409 (1932), aff'd 66 F. (2d) 776 (C. C. A. 2d, 1933).

4. Carr v. Commissioner, $28 \mathrm{~F}$. (2d) 55 I (C. C. A. 5th, I928) ; Nott-Atwater Co. v. Poe, 33 F. (2d) 1000 (W. D. Wash. 1928), aff'd per cur. 42 F. (2d) 1018 (C. C. A. 9th, 1930); Putnam Nat'l Bank v. Commissioner, 50 F. (2d) I58 (C. C. A. 5th, 193I).

5. 59 F. (2d) 320 (C. C. A. 6 th, 1932).

6. I4 B. T. A. I428 (1929).

7. 59 F. (2d) 320 at 325 (C. C. A. 6th, 1933). 
worthlessness of the debt in previous years to the prejudice of the government, and even if taxpayer is not estopped, the amounts received were chargeable to income under the principle announced in Burnet $v$. Sanford \& Brooks Co. ${ }^{8}$ In a later case, the Board was again faced with this problem and without discussion of its former position, held that the recovery of a debt improperly deducted was income, and this decision was affirmed by the Circuit Court of Appeals. ${ }^{9}$

\section{B. Reimbursement of Expenses Previously Deducted}

The view generally taken as to the reimbursement of expenses which have been deducted in prior years is that it should be included as income for the year received. Thus, reimbursement from employer to employee for traveling expenses is to be included in the latter's income. ${ }^{10}$ The same is true as to reimbursement of other expense items. For example: taxpayer purchased equipment and gave notes in partial payment. Later taxpayer expended sums in servicing this equipment, because of defects, which he had re-sold, and took deductions therefor. When the seller of the equipment cancelled some of the notes as reimbursement to the taxpayer for loss of profits and expenses, the Board held that the face amount of the notes cancelled should be taken into income in the year of adjustment." In the course of the opinion the Board said: "The use of fixed accounting periods requires that the amount by which expenses, once deducted because paid or acccrued, are reduced by later adjustments must be taken into income in the year of adjustment. Only in this way can the amount of the taxpayer's reported income be made to agree with its actual income." 12

The leading case on this subject is Burnet v. Sanford \& Brooks Co., ${ }^{23}$ where the taxpayer in the returns from I9I 3 to I9I6 deducted expenditures incurred from a United States dredging contract which expenses exceeded the income. Work on this project was abandoned in 1920 and the taxpayer in a lawsuit recovered an amount equal to the excess. The Supreme Court held that the money received in 1920 was properly included by the Commissioner as part of the gross income for that year, again stressing the fact of the practical necessity of computing the tax on the basis of annual or other fixed taxable periods. ${ }^{14}$ Justice Stone in his opinion also points out that the fact that the particular transaction does not result in a profit does not preclude the inclusion of this reimbursement from income. ${ }^{15}$

Another interesting case dealing with this subject is Buffalo Union Furnace Co. v. Helvering. ${ }^{16}$ The taxpayer did its own "car spotting", certain switching operations, from I905 to I9I4, without payment, during which time competitors were either receiving payment for rendering such service or having it rendered by the railroad without charge. Because of this discrimination, as found by the Interstate Commerce Commission, the taxpayer received an amount from the railroad in 1920 . The court held that the taxpayer having deducted the expenses

\footnotetext{
8. 282 U. S. 359 (193I). 1933).

9. Askin \& Marine Co., 26 B. T. A. 409 (1932), aff'd 66 F. (2d) 776 (C. C. A. 2d,

Io. U. S. Treas. Reg. 94, Art. 23 (a)-2 (1936). But see: J. S. Cullinan, 5 B. T. A. 996
} (1927), which held that taxpayer derived no income from repayments of traveling expenses.

Note, however, that no deduction for traveling expenses had been made by the taxpayer.
II. B. F. Avery \& Sons, Inc., 26 B. T. A. I393 (I932).

I2. Id. at 1400 .

13. 282 U. S. 359 (I93I).

14. Id. at 365,366 .

15. See Helvering v. Midland Mutual Ins. Co., 300 U. S. 216, note at 226 (1937): "The exigencies of a tax determined on an annual basis may lead to the inclusion as income of items which might be shown to involve no gain if the transactions were viewed as a whole
over several years."

16. 72 F. (2d) 399 (C. C. A. 2d, 1934). 
in previous years, must surcharge its income for the amount reimbursed.17 Judge Learned Hand differed with the Board ${ }^{18}$ as to the treatment of so much of the amount recovered as was properly apportionable to the period before March I, I9I3, which the Circuit Court of Appeals held, was erroneously surcharged, relying on two cases, one of which was the District Court opinion of United States $v$. Safety Car Heating \& Lighting $\mathrm{Co}^{19}$ After being affirmed by the Circuit Court of Appeals, ${ }^{20}$ this decision was reversed by the Supreme Court. ${ }^{21}$ This indicates that in the Buffalo Union case the whole amount might have been treated as income in 1920 when the contingent claim existing before $19 \mathrm{I} 3$ became unconditional. However, it is to be noted that Justice Cardozo, referring to the Buffalo Union case in his opinion in the Safety Car case, says that it "is perhaps upon the border line", and confines it to its facts. ${ }^{22}$

Recent cases on this subject of reimbursement of expense items previously deducted have followed the rule of the Sanford \& Brooks Co. case. ${ }^{23}$ Similar to these cases are those where an expense item properly accrued and deducted is never paid. Thus, where employees' wages are earned and deducted from income, but never collected and in a later year this unclaimed amount is charged to "profit and loss", this is held as income for that year. ${ }^{24}$

\section{Reimbursement of Losses Previously Deducted}

The authorities relating to reimbursement for losses are not so uniform in their holdings as those relating to bad debts and expenses. The act provides for deduction of losses "sustained during the taxable year and not compensated for by insurance or otherwise". ${ }^{25}$ This provision would seem to prohibit the deduction of losses which are "compensated for by insurance or otherzerise". Ordinarily, a loss may be compensated for in one of two ways: (I) by recovery against an insurer, or (2) by recovery against the person whose conduct has caused the loss. Thus it would seem that if the taxpayer is compensated for in either of these two ways, he is not entitled to take a deduction for this item. Where the compensation is received during the same taxable year in which the loss occurs, no difficulty arises. But suppose the loss occurs in one year and the reimbursement is not received or finally denied until a later year. Moreover, does it make any difference if the liability is or is not disputed.

It seems settled that mere delay in the payment of insurance proceeds, or other reimbursement, does not furnish grounds for a different treatment of the loss deduction. In such case the deduction must be reduced by the amount of the reimbursement, or, in other words, the loss "is compensated for by insurance or otherwise", although actual payment is not received in the same taxable year in which the loss occurs. ${ }^{20}$ And the rule is also applicable to the case where the insurer admitted liability and delay in payment of the claim was due to a dispute as to the amount of the loss. ${ }^{27}$ In this situation, the loss must be taken for the

I7. Id. at 403 .

18. 23 B. T. A. 439 (193I).

19. 5 F. Supp. 276 (D. C. N. J. 1934).

20. 76 F. (2d) I33 (C. C. A. 3d, 1935).

2I. 297 U. S. 88 (1936).

22. Id. at 98 .

23. Wichita State Bank \& Trust Co. v. Commissioner, 69 F. (2d) 595 (C. C. A. 5th, I934), cert. denied 293 U. S. 562 (I934); Commissioner v. John Thatcher \& Son, 76 F. (2d) 24. Charieston \& W. C. Ry. Co. v. Burnet, 50 F. (2d) 343 (Ct. App. D. C. I93I). Accord: Chicago R. I. \& P. Ry. Co. v. Commissioner, 47 F. (2d) 990 (C. C. A. 7th, I93I), cert. denied 284 U. S. $6 \mathrm{I} 8$ (I93I) ; Atlantic Coast Line R. R. Co., 23 B. T. A. 888 (I93I).

25. REv. Act 1936, \$23 (e), 49 STAT. 1658, 26 U. S. C. A. \$23 (e) (Supp. 1937).

26. Worstell Co., Ltd., I5 B. T. A. 413 (I929).

27. Max Kurtz, 8 B. T. A. 679 (I927). 
year in which it occurs, although the amount of the loss is not ascertained and adjustment is not made until a subsequent year. ${ }^{28}$

In the cases to which reference has just been made, the loss was known to the taxpayer when it occurred; there was no dispute as to liability and no doubt that there would be reimbursement. Usually, in these cases the lapse of time between the loss and the reimbursement is comparatively short. However, in other cases, which are the ones which give rise to the most difficulty, there may be great doubt at the time the loss occurs whether reimbursement will ever be obtained and reimbursement, if secured at all, may be years after the occurrence of the loss. The cases fall roughly into three classes: (I) Cases involving theft or embezzlement where the loss is not discovered until after the taxable year in which it occurs, but upon discovery reimbursement is secured without difficulty. (2) Cases in which the legal right to reimbursement is disputed. (3) Cases in which there is no legal right to reimbursement at the time the loss occurs but there is a possibility of reimbursement which is later realized.

(I) Cases involving theft or embezzlement where discovery of the loss is delayed but reinbursement is not disputed. In these cases the right to reimbursement is not disputed and there exists a person financially willing and able to pay, but failure to discover the loss caused considerable delay in the taxpayer's assertion of the right. There is very little case law on this phase of the problem. In a Treasury Department ruling, ${ }^{29}$ a taxpayer discovered in 1916 that funds had been embezzled over a number of years from I903 to 19I6. The funds were taken in such a way that they had never been included in the taxpayer's income. Pointing out that a loss deduction must be taken for the year in which the loss was sustained, it was held that the amount recovered from the embezzler in I9I7 should be accounted for by amending the returns in the years in which the loss was sustained. The reasoning of this memorandum is that an embezzlement loss is to be reduced by any right to reimbursement which, at the time of the loss, is equivalent to cash, e. g., a fidelity bond covering such loss. It does not hold that a mere possibility of recovery affects the amount of the loss deduction. ${ }^{30}$ It is to be noted that this result is reached only by the use of hindsight and viewing the transaction as a whole, and does not deal with the problem on fixed accounting periods which would seem to warrant treating the reimbursement as an item to be included in gross income for the year I9I7.

With the above memorandum is to be compared the Board's decision in South Dakota Concrete Products $\mathrm{Co}^{31}$ In that case funds were embezzled from I922 to I926 and, unknown to the taxpayer, were entered as expenses on the books and taken as deduction from income for those years. In 1926, the embezzlement was discovered and reimbursement for the amounts secured from a third party. The Board held the reimbursement was income for the year in which recovered, pointing out that income tax liability is to be determined on annual periods on the basis of facts as they existed in each period and an adjustment in later years should be reported as income." The opinion continues: "In laying down these rules the courts and the Board have been fully conscious of the fact that losses will sometimes be deducted where the future will eventually disclose compensation, and there will be reported as income that which is in fact only compensation for loss. But the deductions are practical necessities due to our 28. Martin Veneer Co., 5 B. T. A. 270 (I926). But cf. Pike County Coal Corp., 4 B. T.
A. 625 (I926).

29. L. O. 845 , I C. B. II8 (rgrg).

30. To the same effect, see O. D. 165, I C. B. I25 (I9I9).

3I. 26 B. T. A. I429 (1932).

32. Id. at 1432 . 
inability to read the future, and the inclusion of the recovery in income is necessary to offset the deduction." 33

This decision seems inconsistent with the opinion discussed above. In both the taxpayer would seem to have had the benefit of a deduction and taxable income was thus reduced by the amount of the embezzlement, and they therefore seem to present conflicting views as to the manner in which reimbursable losses are to be treated. The ruling takes the position that where reimbursement is obtained after embezzlement this diminishes the amount of the allowable deduction and the return for the year of the embezzlement is to be thus amended. The Board on the other hand held the reimbursement for embezzlement is returnable as income in the year when received. If the possible difference is the fact of the running of the statute of limitations in one case and not in the other, this is neither discussed nor pointed out. From the standpoint of the government the Board's view would seem preferable since the statute of limitations may bar any deficiency assessment for the year of the loss.

(2) Cases in which the legal right to reimbursement is disputed. The cases involved in this category are those in which the right to reimbursement comes, for example, from an insurance company which denies liability, or from an alleged tortfeasor, financially able but unwilling to pay, denying liability. The Board has had several cases involving these situations. Thus, where taxpayer's property was damaged by flood in 1920 and in 1924 judgment was secured against the city which had denied liability, the Board held the taxpayer properly took a deduction for 1920 , when the loss was sustained. ${ }^{34}$ The Board said that since there was a denial of liability at the end of 1920 , and since the taxpayer's only chance of recovery lay in a lawsuit, such a state of facts does not in any manner require the conclusion that the loss was compensated for..$^{35}$

After this indication that losses are to be taken in the year sustained and reimbursement received after dispute is to be treated as income for the year in which received, the Board then reached a different result in a later case. ${ }^{38}$ In this case, taxpayer's warehouse was burglarized in I925 and the insurance company refused to pay the policy covering the loss. Taxpayer brought suit against the insurer, and was denied recovery in 1928 , for which year a deduction was then claimed. The Board held the loss was not sustained until I928 and was therefore a legal deduction for that year. The only possible distinction between these two cases by the Board is factual: in one case, claim is against an alleged tortfeasor denying liability, whereas in the other the claim is against an insurer denying liability. This would not seem to merit the taking of different views on situations so nearly akin to one another ${ }^{37}$ It is interesting to note that in both cases, the Board relied upon and cited United States $v$. White Dental Mfg. Co. ${ }^{88}$

The Board had occasion to deal with this problem again in Highway Trailer $\mathrm{Co}^{39}$ In this case the loss by fire occurred in I921, not covered by insurance,

33. Ibid. Compare with this language that of Brandeis, J., in his opinion in Helvering v. Midland Mutual Ins. Co., 300 U. S. 216, note at 226 (1937), quoted supra note 15.

34. H. P. Robertson Co., I4 B. T. A. 887 (I928).

35. Id. at 889. " - . it would indeed require a high degree of optimism to say, at the close of I920, that the loss suffered would be compensated for, as Justice Stone said in United States v. White Dental Manufacturing Co. of Pennsylvania, 274 U. S. 398, when the provision here under consideration was being considered, "The Taxing Act does not require the taxpayer to be an incorrigible optimist'."

36. Allied Furriers Corp., 24 B. T. A. 457 (I93I).

37. Cf. Edward H. R. Green, I9 B. T. A. 904 (I930) (loss sustained by shipwreck in rgrg held not deductible in 1923 when salvage therefrom disposed).

38. 274 U. S. 398 ( 1927 ), to be more fully discussed under the next subsection dealing with the situation in which no legal right to reimbursement existed at the time of the loss.

39. 28 B. T. A. 792 (I933). 
and the taxpayer had started suit against the party alleged to be responsible which was decided against the taxpayer in 1925. The Board sustained the deduction for the year I925, thus following the Allied Furrier case, ${ }^{40}$ and again holding that the loss was sustained in the year in which it was decided there was no liability on the party alleged to be responsible. However, the Circuit Court of Appeals reversed the Board ${ }^{41}$ and held that entire deduction should have been taken in Ig2r, the year when the fire occurred. In the course of the opinion, the court stated:" "Where... an actual physical loss occurs, resulting in a certain definite, fixed amount of damage, it seems better practice to allow the deduction for that entire amount of damage (not covered by insurance) in the year in which the loss actually occurs, according to the rule in the White Dental case, rather than to defer it until subsequent events indicate whether or not a recovery is to be had from other parties for a part of the loss." This seems consistent with the theory of income taxation at regular intervals as advanced by Justice Stone in the Sanford $\mathcal{E}$ Brooks Co. case. ${ }^{43}$ The dissent, on the other hand, states that the loss should not be allowed as a deduction until "realization", usually evidenced by some closed or completed transaction which did not occur until I925, when the court decided against the taxpayer. ${ }^{44}$ The Supreme Court denied certiorari in this case and thus acquiesced in the view taken by the majority of the Circuit Court.45

Substantially this same view was expressed by the Circuit Court of Appeals for the Second Circuit in Commissioner v. John Thatcher \& Son. ${ }^{46}$ In that case the taxpayer, a general building contractor, had a claim against defaulting subcontractors for damages in the amount by which cost of completing their work exceeded the amount received by the general contractor. This claim was decided against the contractor in I928, for which year he then claimed a deduction. The court held the deduction should have been taken in the years it was paid. There were two bases for the opinion: First, the amount paid to complete the work was an "ordinary and necessary expense" deductible when paid. Second, that it was a loss not compensated by insurance or otherwise, since the claim against the subcontractors was too contingent to be regarded as compensation. Judge Learned Hand concurred only on the "loss" view, with which we are here concerned. The court states: "If the liability of the obligor [subcontractor or surety] is too contingent to be accrued as a loss to him [because of assertion of claim which was disputed], it would seem to follow that the claim of the obligee is likewise too contingent to be considered compensation for a loss already realized by the latter." 17

The Circuit Court of Appeals for the Fourth Circuit has also taken this view. Thus, in Niagara Share Corp. v. Commissioner, ${ }^{48}$ where the taxpayer had a contract guaranteeing against loss through the sale of securities, and sold securities at a loss in I930, guarantors denying liability, and the controversy not being settled until I934, the court held that taxpayer may deduct loss in the year when suffered and pay a tax on the amount of the loss, if any, in the year when recovery is made. The court by their decision reversed the Board. ${ }^{49}$

40. 24 B. T. A. 457 (I93I), cited supra in 36.

4I. Commissioner v. Highway Trailer Co., 72 F. (2d) 913 (C. C. A. 7th, 1934).

42. Id. at gr 5 .

43. See supra p. 869 .

44. 72 F. (2d) 9r3 (C. C. A. 7 th, I934) at 9 I5.

45. 293 U. S. 626 (I935).

46. 76 F. (2d) 900 (C. C. A. 2d, r935), cited supra note 23.

47. Id. at 902 .

48. 82 F. (2d) 308 (C. C. A. $4^{\text {th, I936). }}$

49. 3 I B. T. A. 832 (I934). 
When the Board again was faced with this problem it reversed its position to accord with the above-mentioned circuit court decisions. ${ }^{50}$ But in the very next case to reach the Board involving this same point, the Board once more shifted its position. In Henry S. Cahn ${ }^{51}$ the taxpayer's store was burglarized in I924. The insurers, Lloyds of London, denied liability and because the insurer had no agent within the state and suit abroad would have been necessary, taxpayer's attorney advised against pursuing the claim, and the taxpayer deducted the amount of the loss for I924. Suit against the insurance company was settled in 1925. The Board held, sustaining the Commissioner, that the loss deduction should be reduced by the amount recovered. This position seems inconsistent with that taken by the Commissioner in most of the cases previously discussed, particularly in the Highway Trailer Co. case..$^{52}$ However, the Board's decision was reversed by the Circuit Court of Appeals for the Ninth Circuit which held that the taxpayer was entitled to a full deduction for the year of the burglary, notwithstanding that the claim was compromised and part of the amount of the loss recovered the following year. ${ }^{53}$ This is fully in accord, then, with the previous decisions. When the loss is complete in the year in which it occurs, regardless of whether recovery is had on a disputed claim for reimbursement, it is deductible for that year. This is a clear indication that the reimbursement for the loss is to be treated as income in the year in which it is received. ${ }^{54}$

(3) Cases in which no legal right to reimbursement existed at the time of the loss. In this class is found cases involving suits against municipalities immune from suits or cases dealing with war losses. The leading case is United States v. White Dental Mfg. Co. ${ }^{55}$ In this case the taxpayer owned assets in a German corporation taken over by the German government during the war in I9I8, for which year the taxpayer deducted the amount of the loss. In I922, recovery of part of the sum was realized and also a claim for the remainder was allowed by the Mixed Claims Commission. The Supreme Court held the deduction for I9I8 was proper, saying: "It is enough to justify the deduction here that the transaction causing the loss was completed when the seizure was made." ${ }^{56}$

In these cases there is no conflict as to the year for which the loss is to be taken. One enters the field of controversy in determining how the reimbursement should be treated when received. Much of the conflict can be traced to the peculiar decision by the Supreme Court in Bozers v. Kerbaugh-Empire Co. ${ }^{57}$ In that case the taxpayer in I92I repaid loans made for its German subsidiary and because of the fluctuation of the mark, the amount repaid was less than the amount borrowed. The subsidiary had lost the money borrowed and had taken a deduction therefor. The Court held, overruling the Commissioner's contention, that the gain resulting from the liquidation of the liability at less than the amount borrowed was not taxable income for rg2r, saying that "the result of the whole

50. Carolina Contracting Co., 32 B. T. A. II7I (I935) (taxpayer required to finish work for defaulting subcontractor in I932 entitled for deduction for that year despite pending litigation against subcontractor).

5I. 33 B. T. A. 783 (1935).

52. See supra pp. 872, 873.

53. Cahn v. Commissioner, 72 F. (2d) 674 (C. C. A. 9th, 1937).

54. See Commissioner v. John Thatcher \& Son, 76 F. (2d) 900, 90 I (C. C. A. 2d, 1935): "Had it [the taxpayer] succeded in recovering damages from the subcontractor or their sureties, such recovery would have been income in the year when received."

55. 274 U. S. 398 (1927).

56. Id. at 402. To the same effect see, James H. Post, I2 B. T. A. 5Io (I928) (loss in I920 through acts instigated by Government deductible in that year despite compensation received through special act of Congress in 1923).

57. 27 I U. S. I70 (1926). 
transaction was a loss", 58 and "the mere diminution of a loss is not gain, profit or income". .9

Emphasis in this opinion is shifted from dealing with income taxation on fixed accounting periods to viewing the transaction involved as a whole, regardless of income intervals. By the reasoning of this case, no receipt may be included in gross income if it is derived from a transaction which, considered as a whole, has resulted in a loss, although such loss had been deducted from gross income in prior years. In only one case has this broad proposition been applied successfully..$^{\circ}$

It should be noted that this last mentioned decision was handed down before the Sanford \& Brooks Co. decision by the Supreme Court. ${ }^{61}$ In that case the Court said, "The excess of gross income over deductions did not any the less constitute net income for the taxable period because respondent, in an earlier period, suffered net losses in the conduct of its business which were in some measure attributable to expenditures made to produce the net income of the later period." 62 Thus, in the light of this decision it can be said that the Kerbaugh-Empire decision seems safely pigeon-holed to the special facts-discharge of a liability by depreciated currency-without having to say that the case was wrong to begin with. Therefore, it is not unsound to say that a receipt of money or property may be included in gross income although received as compensation for a loss suffered in prior years.

\section{Reimbursement or Recovery of Taxes Previously Deducted}

(I) Cases in which taxes were erroneously deducted. The first problem that arises here is whether a deduction may be taken at all. If not, it would seem that any deductions taken should be disallowed irrespective of whether a refund is or is not secured. In the first cases to come before the Board, a refund had been secured and the question was whether the Commissioner could disallow the deduction, the statute of limitations not yet barring such action. In one case, ${ }^{63}$ the taxpayer paid state inheritance tax in I922, which was taken as a deduction in his return for that year. In I924, the state act was declared unconstitutional and in 1925, the taxpayer recovered back the tax paid. The Board held the deduction from gross income for I922 was not a legal one and disallowance and deficiency assessment by the Commissioner was proper. The question whether the deduction could have been disallowed in the absence of a refund of the taxes paid was presented in a later case. ${ }^{64}$ In that case the taxpayer in I923 paid taxes under an act declared unconstitutional in I928. The Board held this to be deductible for I923, not as a tax but as a loss, since no refund had been secured and there was little chance of this. But a subsequent Board decision ${ }^{65}$ held taxes paid under an unconstitutional act were properly deductible as taxes.

The first cases presented to the Circuit Courts dealing with this question were decided in accord with the above-mentioned Board cases, to the effect that deductions for taxes, subsequently refunded, should be disallowed where the statute of limitations does not bar such action. Thus, in Inland Products Co. $v$. Commissioner ${ }^{60}$ where the taxpayer in IgI9 and I920 paid taxes under regula-

58. Id. at I75.

59. Ibid.

60. Barton \& Fales, Inc. v. Commissioner, $4 \mathrm{r}$ F. (2d) 339 (C. C. A. Ist, 1930).

6r. 282 U. S. 359 (I93I), discussed supra p. 869 .

62. $I d$. at 364 .

63. Phillip C. Brown, Io B. T. A. I122 (1928).

64. E. L. Bruce Co., I9 B. T. A. 777 (1930).

65. Charles F. Fawsett, 3o B. T. A. 908 (1934).

66. 3I F. (2d) 867 (C. C. A. 4th, I929). 
tions declared void in 1924 and received a refund of the taxes paid, the Circuit Court for the Fourth Circuit held the income tax return could be readjusted to eliminate the deduction. Other Circuit Courts have dealt with the problem in the same way. ${ }^{67}$

In the Inland Products case, the court expressly says it does not decide what the result would be in a case where readjustment would be barred by the running of the statute. ${ }^{68}$ It is to be noted that in none of the cases decided by the Circuit Courts up to this point had the Commissioner contended that the refund be included in gross income for the year in which received, although this was the contention of the taxpayer in the Inland Products case which was not sustained. But in Houbigant, Inc. v. Commissioner, ${ }^{69}$ the Commissioner was forced to make this contention. In that case the taxpayer paid custom duties under protest from 1924 to I929. In I93I, the duties so paid and previously deducted were refunded. The duties had been included in the cost of the goods sold in the taxpayer's return for the proper prior applicable years and the statute of limitations barred adjustment in deductions and the assertion of additional taxes for the years I924 to I929. The Board, sustaining the contention of the Commissioner, held the amount recovered by way of refund constituted income for the year in which received. The taxpayer's contention that the running of the Statute of Limitations could not make income of an item which otherwise would not be income was answered by the Board in this fashion: "Having been deducted in prior returns, if they are not taken up in gross income when recovered, the petitioner clearly over a series of years, escapes tax upon gains and profits equaling the amount of the custom duties recovered. It cannot be presumed that such a result was contemplated by Congress. Furthermore, from any standpoint, the petitioner was enriched by the recoveries of the import duties in the fiscal year ended June 30, I93I. The argument that the income received from this source is exempt from tax has no support in the law." ${ }^{70}$ The Board's decision was affirmed per curiam by the Circuit Court of Appeals for the Second Circuit ${ }^{71}$ and certiorari was denied by the Supreme Court. ${ }^{72}$

The problem of how a refund for taxes erroneously paid and deducted is to be treated was more recently again presented to the Circuit Court of Appeals for the Seventh Circuit. In Nash v. Commissioner, ${ }^{73}$ the taxpayer pursuant to state income tax law paid taxes on his wife's income from I926 to I93 $\mathrm{r}$, when the tax law was declared unconstitutional by the United States Supreme Court, and in 1932, the state refunded to the taxpayer the amount paid, plus interest, the latter item conceded to be taxable by the taxpayer. Further assessment of federal taxes for the years I926-r93I, to correct assessments for those years, was barred by the Statute of Limitations. The court held that a refund resulting from the return of taxes previously paid under a mistaken view of the validity of a state tax is taxable. The Supreme Court's stamp of approval to this holding is again marked by the denial of certiorari. ${ }^{74}$

Before the Houbigant and Nash cases, the position of the Commissioner's office was reflected by a mimeographed letter ${ }^{75}$ which provided that if custom duties or taxes so deducted from gross income were legally collected, refunds

67. See Leach v. Commissioner, 50 F. (2d) 372, 373 (C. C. A. Ist, I93I); Bergan v. Commissioner, 80 F. (2d) 89, 9r (C. C. A. 2d, I935).

68. 31 F. (2d) 867 , at 869 (C. C. A. $4^{\text {th }}$, I929).

69. 3I B. T. A. 954 (1934).

7o. Id. at 956.

7I. 80 F. (2d) Ior2 (C. C. A. 2d, I936).

72. 298 U. S. 669 (1936).

73. 88 F. (2d) 477 (C. C. A. 7 th, 1937).

74. 30I U. S. 700 (1937). Accord: Victoria Mills Paper Co., 32 B. T. A. 666 (1935).

75. Mim. 3958, C. B. XI-2, 33 (1932). 
thereof should be treated as income for the year in which refunded and if such duties or taxes were illegally collected adjustment should be made in the returns of the taxpayers for the years in which the deductions were taken. This position was taken and adhered to with full awareness of the fact the Statute of Limitations would bar adjustments in some cases for prior years and the taxpayers would thus escape from taxation. The thought would seem to have been that legislation was the proper remedy. However, after the Houbigant and Nash cases and with those cases as authority, a new mimeographed letter by the Commissioner, superseding all previous inconsistent rulings, was issued. ${ }^{78}$ In this ruling it is stated that in case of a refund in any year of custom duties illegally deducted which have been taken as deductions in federal income tax returns for a prior year, if the taxable year in which the deduction taken was closed by expiration of the period of limitation for the making of additional assessment of income tax, or by reason of the prior execution of a final closing or compromise agreement, or by a stipulation before the Board of Tax Appeals or the courts the refund should be treated as income for the taxable year in which it is made. As to legally collected taxes and duties deducted, there is no change-income when refunded.

To summarize, it can be said:

(I) Amounts erroneously paid as taxes may be deducted as taxes, expenses or losses where no refund has been, or is likely to be, secured.

(2) Refunds of taxes erroneously paid must be accounted for by disallowing the tax deductions taken, where such disallowance is not barred by the Statute of Limitations.

(3) When the disallowance of the tax deduction is barred, the refund is to be treated as income for the year in which it is received.

One problem still remains. Suppose the Statute has not yet run: is the Commissioner obliged to follow the method of disallowing deductions and adjusting income, ${ }^{77}$ or may he, on the other hand treat the refund as income in the year when received, in the same way as if the Statute had run. ${ }^{78}$ Is the Commissioner to pursue an opportunistic policy, using one method or another at his option. This problem has as yet not been presented to the courts and it will be interesting to note how the situation will be treated.

(2) Cases in which reimbursement for taxes paid is received from a third person. There seems to be no conflict of opinion in this type of case. Thus, where under sales contracts, purchaser of lots agreed to pay taxes on such lots, security title remaining in the taxpayer, and the taxpayer collected the amount of the taxes from the purchasers, commingled the sums with other funds and paid the taxes on the entire property, taking a deduction therefor, it was held that the amount collected from the lot purchasers should be included in gross income for the year received. ${ }^{79}$. Such a result seems fully in accord with and correct on the basis of the Sanford \& Brooks Co. case.

\section{Conclusion}

It may be suggested that the entire problem of reimbursements may be remedied by a proper provision in the Revenue Act making all such reimbursements income for the year received. But until this is done, the following conclusions can be made from a reading of the decisions and rulings: Any reimburse-

76. Mim. 4564, C. B. XVI-I, 93 (1937).

77. Inland Products Co. v. Blair, 3I F. (2d) 867 (C. C. A. 4th, I929).

78. Houbigant, Inc. v. Commissioner, 80 F. (2d) IoI2 (C. C. A. 2d, 1936), cert. denied 298 U. S. 669 (I936); Nash v. Commissioner, 88 F. (2d) 477 (C. C. A. 7th, 1937), cert.
denied 30r U. S. 700 (1937).

79. Trust No. 5522, etc. Security-First Nat'l Bank, 27 B. T. A. I250 (I933), rev'd on other grounds Trust No. 5522, etc. v. Commissioner, 83 F. (2d) 8or (C. C. A. 9th, 1936). 
ment of an item properly deducted in a prior year should be included in income for the year in which received. To determine whether an item is properly deductible or not the circumstances and the conditions as they appeared and existed as of the time the deductions are taken should be examined. Any deduction improperly made should be adjusted wherever such is possible, regardless of reimbursement. If the Statute of Limitations bars adjustment, then and only then should the reimbursement for an item improperly deducted be included in income.

\section{L.S.}

\section{Liabilities of Transferor and Transferee of Shares for Calls and Assessments}

A common problem confronting the courts concerns the duties of a transferor or transferee of corporate shares to respond to calls or assessments made upon those shares. Although there has been a considerable amount of case law upon the subject, little has been written on the general problem, as to the extent, if any, to which each party is liable in the different situations arising in connection with stock transfers. ${ }^{1}$

Strictly speaking, a "call" is a demand upon a shareholder for the unpaid balance of the purchase price of his shares. ${ }^{2}$ On the other hand, an "assessment" is a demand for a contribution in excess of the par value of the stock, based upon liability created by statute, the corporate articles or by-laws, or by contract between the subscriber and the corporation. ${ }^{3}$ Nevertheless, there seems to be no necessity for separate discussion of the various types of demands in the present article since, once the validity of the call or assessment has been determined, the courts appear to apply a single method in deciding whether the transferor or the transferee of shares is the one who must pay.

In all cases where shares are subject to call or assessment, there exists a potential source of revenue to the corporation; consequently, the transfer of such shares affects both the corporation and its creditors as well as the two immediate parties to the transaction. Thus, in determining the proper person to answer a call or assessment, the interests of the corporation and the corporate creditors should not be overlooked.

Probably the fundamental factor in determining liability for call or assessment is that of registration of the transfer on the books of the corporation. At common law, if the corporation did not require registration, an unrecorded transfer was valid between the parties and against the corporation and its creditors. ${ }^{4}$ However, provisions in the corporate articles of association or by-laws for registration of transfers are almost universal, and a large number of the states have made recording mandatory by statute. ${ }^{5}$ With the exception

I. See Notes (1932) 30 Mich. L. REv. I270; (1932) 80 U. OF PA. L. REv. II33; (I932) 4I YALE L. J. 583. These deal with the general problem insofar as bank shareholders are involved.

2. Campbell v. American Alkili Co., I25 Fed. 207, 209 (C. C. A. 3d, I903); Wall v. Basin Mining Co., I6 Idaho 3r3, 324, IoI Pac. 733, 737 (I909) ; Newman v. Sexton, I56 III. App. 517, 519 (1910).

3. Seyberth v. American Commander Min. \& Milling Co., 42 Idaho 254, 264, $245 \mathrm{Pac}$. 392, 395 (1926) ; Porter v. Northern Fire \& Marine Ins. Co., 36 N. D. 199, 207, 16I N. W. I0I2, I0I4 (IgI7) ; Price's Appeal, I06 Pa. 421, 429 (I884).

4. I2 Fletcher, Cyclopedia of the Law of Private Corporations (Perm. ed. 1932) $\S 5489$, and cases cited therein in note 67 .

5. The statutes of at least eighteen states have specific provisions for registration of share transfers, and the majority of others assume that transfers will be recorded by making provisions as to where such records shall be kept. The statutes are collected in the CorPorATION MANUAL (39th ed. I938), topic 20. 
of two Alabama decisions which hold that the purpose of the recording statutes is to protect the creditors of the individual shareholders, ${ }^{6}$ the general view is that recording is for the convenience and protection of the corporation and its creditors. ${ }^{7}$ The effect which this interpretation of the purpose of the recording requirements has in determining whether the transferor or transferee will be liable for calls or assessments cannot be overemphasized.

\section{Liability of the Transferor}

(a) Prior to Recording the Transfer: Where a transfer of shares has been made from $A$ to $B^{8}$ in the absence of any requirements for recording, and the corporation has assented to the transfer, it has been held that $A$ is relieved from further liability for calls in actions brought by creditors of the corporation. ${ }^{9}$ There would seem to be no reason to permit creditors to object to shareholder changes of a solvent corporation. There are even greater reasons for applying the same rule to an action by the corporation, since, by hypothesis, it had approved the transfer. It would seem, therefore, that in cases where there are no requirements that transfers be recorded on the books of the corporation, the transferor should be relieved from further liability to the corporation for calls or assessments provided that the corporation is given the opportunity to refuse to release $A$ from liability where the financial responsibility of $B$ is doubtful. As to the creditors of the corporation, the same rule should apply to them, unless it were shown that the corporation, at a time when it was insolvent, had acquiesced in a scheme to substitute a financially irresponsible person for one able to respond when his liability is asserted.

More common, however, is a suit against the transferor where he has failed to comply with the requirements of recording which now exist in almost every case. Where $A$ has transferred to $B$, but no recording has been made, $A$, as the shareholder of record, remains liable for calls and assessments irrespective of whether suit is brought by the corporation, ${ }^{10}$ the creditors of the corporation, ${ }^{11}$ or the receiver. ${ }^{12}$ This rule is manifestly desirable since neither the corporation nor its creditors have had the opportunity to determine the identity of the transferee, nor has the corporation been able to examine the transferee's financial responsibility. Furthermore, the transferor does not thereby lose his rights against his transferee and can look to him for repayment of the amount which he has had to furnish. ${ }^{13}$

(b) After an Ineffectual Attempt to Obtain Recording: It sometimes happens that, although no actual recording has been made, there has been an attempt by the transferor to have the corporation make the proper registration. In such

6. Henderson v. Mayfield Woolen Mills, 153 Ala. 625, 45 So. 211 (1907) ; Hall \& Farley v. Alabama Terminal \& Improvement Co., 173 Ala. 398, 56 So. 235 (I9ri).

7. I2 FleTCHER, op. cit. supra note $4, \S 5489$, n. 75 and 79.

8. Throughout this article, the transferor will be designated as $A$, the transferee as $B$.

9. Allen v. Montgomery R. R., II Ala. 437 (I847); Dain Mfg. Co. v. Trumbull Seed Co., 95 Mo. App. I44, 68 S. W. 95 I (I902).

10. Giesen v. London \& N. W. American Mfg. Co., roz Fed. 584 (C. C. A. 8th, I900); Campbell v. American Alkili Co., r25 Fed. 207 (C. C. A. 3d, rg03); Mutual Oolitic Cut Stone Co. v. Colgren, 9r Ind. App. 686, r73 N. E. 334 (I930).

II. Knickerbocker Trust Co. v. Meyer, r33 Fed. 764 (M. D. Pa. 1904) ; Wallace \& Tiernan Co. v. Davis, 227 Ky. 7I, II S. W. (2d) 990 (I928); Bell's Appeal, Ir5 Pa. 88, 8 Atl. 177 (1886) ; McCord's Appeal, 212 Pa. 177, 6r Atl. 804 (Ig05).

12. Price v. Whitney, 28 Fed. 297 (D. Mass. I886).

I3. Thus, in Broderick v. Alexander (Kahn), 268 N. Y. 306, I97 N. E. 29I (I935), I3 N. Y. U. L. Q. REV. 319, the transferor was permitted to interplead the transferee, and, after judgment had been rendered against the transferor in favor of the receiver of the corporation, the former recovered judgment in a cross-claim against the transferee. Accord: Hardoon v. Belilios, [rgor] A. C. II8. 
a case, the corporation cannot later urge the absence of recording as a ground for recovery from the transferor ${ }^{14}$ unless the notification has been insufficient. ${ }^{15}$ This view seems correct inasmuch as the corporation, where it has been properly notified of the transfer, should not later profit by its own failure to satisfy technical requirements.

Where the suit is brought by the creditors of the corporation, court decisions, for the most part, parallel those where the corporation is plaintiff, holding the transferor immune to payment where he has made a bona fide attempt to have the transfer recorded, ${ }^{16}$ but permitting recovery by the creditor where the court deems the attempt insufficient ${ }^{17}$ or where the corporation refused to record the transfer for a valid reason. ${ }^{18}$ Nevertheless, it is to be noted that the courts seem more inclined to question the sufficiency of the attempt to have the transfer recorded than in suits brought by the corporation. ${ }^{19}$ The records and accounts of the corporation constitute the only available source of information to creditors as to the identity and financial responsibility of corporate shareholders. Moreover, the shareholder, as a member of the corporation, is in closer contact with, and has greater control over, corporate affairs. It is submitted, therefore, that the courts should develop a different rule for creditors' suits, and permit recovery regardless of whether the failure to record resulted from the carelessness of the transferor or the misbehavior of the corporation.

(c) After Recording the Transfer: Once the transfer has been recorded by the corporation, and the transferee recognized as a shareholder, the transferor should be relieved of further liability for calls or assessments so long as the transfer has been made in good faith. ${ }^{20}$ Furthermore, it should make no difference whether action is brought by the corporation or the corporation's creditors, for the recording amounts to acceptance of the substitution by the corporation and notice thereof to its creditors. So well accepted is the view that the transferor is no longer liable, that few cases seem to have reached the appellate courts on this point. ${ }^{21}$

One notable exception to this general rule appears in the case of a transfer to one who is not legally responsible. Thus, a recorded transfer to an infant, even though made in good faith, and without knowledge of the transferee's

I4. Bank of Toccoa v. Bond, 44 Ga. App. 450, 16r S. E. 636 (193I) ; Ishan v. Buckingham, 49 N. Y. 216 (1872) ; Stewart v. Walla Walla Printing \& Pub. Co., I Wash. 52I, 20 Pac. 605 (1889).

I5. Bank v. Richardson, IIy Kan. 695, 232 Pac. I070 (I925).

I6. Warren v. Nix, 97 Ark. 374, I35 S. W. 896 (I9II); Andrew v. Sanford, 212 Iowa 300,233 N. W. 529 (I930), I7 Iowa L. Rev. 100 (I93I); Schmitt v. Kulamer, 267 Pa. I, Iro Atl. I69 (I920) (action by receiver); Iverson v. Bradrick, 54 Wash. 633, I04 Pac. I30 (I909); Walton Lumber Co. v. Commonwealth Lumber Co., 95 Wash. 295, 163 Pac. 762 (1917).

I7. Realty \& Rebuilding Co. v. Fillmore Arcade Co., 65 Cal. App. 757, 224 Pac. 1020 (I924); Broderick v. Aaron, 268 N. Y. 4Ir, I98 N. E. II (I935) (suit by Superintendent of Banking).

I8. Russell v. Easterbrook, 7 I Conn. 50, 40 Atl. 905 (I898) ("Transferee" refused to accept the shares).

I9. In many of the cases where the creditors were denied recovery although there had been no recording, there were other records of the corporation which showed the transfer. See for example, Iverson v. Bradrick, 54 Wash. 633, I04 Pac. I30 (rgog) (certificate book); Walton Lumber Co. v. Commonwealth Lumber Co., 95 Wash. 295, I63 Pac. 762 (1917) (certificates placed in minute book).

20. Subject to possible exceptions in the case of creditors existing at the time of the transfer discussed infra.

2I. The following cases set forth the general rule: Earl v. Carson, I88 U. S. 42 (1903); Tucker v. Gilman, I2I N. Y. I89, 24 N. E. 302 (I890) ; Efird v. Piedmont Land Imp. \& Inv. Co., 55 S. C. 78,32 S. E. 758 (1899) ; Loomis v. Verenes, I4I S. C. 145, I39 S. E. 393 (I927). 
infancy, will not relieve the transferor of liability to either the corporation or its creditors. ${ }^{22}$ The effect of this rule is to place the burden of ascertaining the responsibility of the transferee upon the person who is in the best position to determine it, and the reasonableness of this exception does not appear to have been questioned.

(d) Fraudulent Intent of Transferor: In Fletcher's Cyclopedia of the Law of Private Corporations, it is stated that "Where the transfer is merely colorable, as, where the transferor seeks to avoid liability to creditors, the transferor remains liable for the amount unpaid on his subscription, especially if the transfer is made when the corporation is insolvent." ${ }^{23}$ Although Fletcher has correctly stated the accepted dogma, ${ }^{24}$ the difficulty before the courts lies in determining what constitutes a colorable transfer which amounts to bad faith on the part of the transferor. Probably the most common reason for selling shares is that the vendor believes that he can make a more advantageous investment. Of necessity, such belief is based to a certain extent upon knowledge of the affairs of the corporation. To hold that a transferor can not relieve himself from further liability for calls or assessments merely because the financial condition of a corporation is dubious, would amount to virtual prohibition of the transfer of corporate shares. Therefore, it would seem that the liability of the transferor should be strictly limited to cases where it is shown that the purpose of the transfer was not only to avoid personal liability, but was done with the knowledge that the transferee was incapable of bearing the responsibility. In Banta v. Hubbell, ${ }^{25}$ suit was brought against the transferor on behalf of the corporation. In refusing recovery, the court stated: ". . . the burden is on the plaintiff who is attacking the transfers on the ground of fraud to show either by direct or circumstantial evidence that at the time of the transfers both the corporation and the transferee were insolvent and the transferors had knowledge of these facts." 26 It would seem that the Missouri court has expressed the proper view, regardless of whether suit is brought by the corporation or on behalf of the creditors.

Once it has been determined that the transfer was made with intent to avoid liability, the courts agree that the transfer will be disregarded and the transferor will be liable for calls and assessments. ${ }^{27}$ However, even where there is evidence of bad faith upon the part of the transferor, it has been held that complete acquiescence in the transfer by the corporation in making the transferee the shareholder of record, and continuous treatment of him as such, will prevent the corporation from later changing its mind and seeking to hold the transferor. ${ }^{28}$ This exception to the general rule should not be extended as a bar to creditors who have had no part in the transaction, and an Alabama case has so held, ${ }^{29}$ stating that the corporation's release of a solvent shareholder and

22. Early v. Richardson, 280 U. S. 496 (I930), 43 HaRv. L. REv. II50; Cobb v. Bank of Martin, 46 Ga. App. Io, I66 S. E. 424 (1932), I7 Minn. L. Rev. 546; Mann's Case, L. R. 3 Ch. App. 459n. (1867); Symon's Case, L. R. 5 Ch. App. 298 (1870).

23. I3 FIETCHER, op. cit. supra note 4, §6109.

24. See cases cited infra note 27 .

25. I67 Mo. App. 38, I50 S. W. 1089 (1912). (1899).

26. Id. at 45, I50 S. W. at IogI. See Foster v. Row, I20 Mich. I, 21 79 N. W. 696, 703

27. Bowden v. Johnson, ro7 U. S. 25I (1882) ; Utica Fire Alarm Telegraph Co. v. Waggoner Watchman Clock Co., I66 Mich. 6I8, I32 N. W. 502 (I9II) ; McCaslin v. Albertson, 279 Mich. 650, 273 N. W. 302 (1937); McConey v. Belton Oil \& Gas Co., 97 Minn. 190, 106 N. W. 900 (I906); see Richmond v. Irons, I21 U. S. 27, 58 (I886); Warren v. Nix, 97 Ark. 374,388 , I35 S. W. 896 , g0I (I9II).

28. Rochester \& Kettle Falls Land Co. v. Raymond, 158 N. Y. 576, 53 N. E. 507 (1899). (Ig04).

29. Hall \& Farley v. Alabama Terminal \& Improvement Co., I43 Ala. 464, 39 So. 285 
acceptance of one who is financially irresponsible " . . . is in legal effect the transfer of property by the corporation to the solvent subscriber without consideration, which is fraudulent and void as to the creditor. . . ." 30

(e) Creditors Who May Show Fraud in the Transfer: Where it has been shown that the transfer of shares from $A$ to $B$ was in fact fraudulent, and made with the intent to enable $A$ to escape liability for payment, the question arises as to which creditors have been so injured by the transfer that they should be permitted to recover. The heavy weight of authority holds that only those persons who were creditors at the time the transfer was made are entitled to recover. ${ }^{31}$ As stated in the majority opinion in McDonald v. Dewey," "In the event of . . . insolvency it is only existing creditors who can claim to have been damnified by a fraudulent transfer of shares. As to them such transfer is voidable. Subsequent creditors are apprised by the published list of the names of the shareholders, to whom transfers have been made, and of the persons to whom they may have recourse for the double liability." ${ }^{33}$ Although the reasoning of McDonald $v$. Dewey has been expressly disapproved by one court, ${ }^{34}$ it would seem that the minority view would only lead to fruitless litigation by subjecting every transfer, no matter how long previously it had been made, to scrutiny by creditors who have had ample opportunity to examine the affairs of the corporation before electing to deal with it.

(f) Continuing Liability of Bona Fide Transferors: Where the transfer from $A$ to $B$ has been in complete good faith and there has been at least substantial compliance with recording requirements, the courts are in complete accord that $A$ is not to be subjected to calls or assessments made for the benefit of any persons who become creditors subsequent to the transfer. ${ }^{35}$ However, there is a definite split of opinion as to whether the transferor should be relieved of liability to those who were creditors before the transfer. Several courts have construed their state assessment statutes so that even a bona fide transferor remains liable to existing creditors, no matter how long subsequently a demand is made, ${ }^{36}$ while other courts have reached this conclusion without statutes. ${ }^{37}$ This view has resulted in extreme hardship upon innocent persons. In the recent Illinois case of Bombal $v$. Peoples State Bank of Ramsey, ${ }^{88}$ the defendant had transferred her six shares of bank stock to her husband so that the latter could qualify as a director of the bank. Later, the husband was able to obtain six other shares which he had transferred to his wife to compensate for the original six. All of the transfers were recorded. When, some time subsequently, the bank failed, the wife was held liable to a full assessment upon both her original six shares as well as the subsequent six, since the bank had incurred debts during the period she first held shares. This decision clearly shows the preferability of a contrary view expressed in two early cases, namely

30. $I d$. at 482,39 So. at 29 r.

31. McDonald v. Dewey, 202 U. S. 510 (1906) ; Bank of Midland v. Harris, II4 Ark. 344,

I70 S. W. 67 (1914); Butts v. King, I0I Conn. 29I, I25 Atl. 654 (I924).

32. 202 U. S. 510 (1906).

33. $I d$. at 529 .

34. Newton v. Bennett, 159 Ga. 426 , I26 S. E. 242 (1924).

35. Walton Lumber Co. v. Commonwealth Lumber Co., 95 Wash. 295, I6I Pac. 762 (I9I7) ; see McDonald v. Dewey, 202 U. S. 510,529 (I906).

36. Cohen v. North Ave. State Bank, Io N. E. (2d) 823 (Ill. App. I937) ; Gunnison v.

United States Inv. Co., 70 Minn. 292, 73 N. W. I49 (1897).

37. Hawkins v. Citizens' Inv. Co., 38 Ore. 544, 64 Pac. 320 (IgOr) ; see Hall v. Hughes, I 19 Md. 487,49 I, 87 Atl. 387,389 (I9I2).

38. Io N. E. (2d) 65I (IIl. I937). 
that a bona fide recorded transfer relieves the transferor of any further obligation to the creditors of the corporation. ${ }^{39}$

\section{Liability of the Transferee}

(a) Before Recording of the Transfer: Where no recording of the transfer between $A$ and $B$ has taken place, several courts have taken the position that the transferee cannot be held liable for calls or assessments either where the suit is brought in behalf of the corporation ${ }^{40}$ or the corporate creditors. ${ }^{41}$ However, in Bru $v$. White, ${ }^{42}$ where the receiver brought suit for statutory assessment against the unrecorded transferee, the court stated the accepted doctrine that the purpose of recording was for the benefit of the corporation and its creditors, ${ }^{43}$ who should be permitted to waive non-compliance, 44 and held that the transferee, as the real owner of the stock, was liable for the assessment. ${ }^{45}$ Although the view taken by the court in Bru $v$. White seems to be that of the minority, it is suggested that it is the proper one. It is not inconsistent with the rule imposing liability upon the transferor where there has been no recording, since, as has been pointed out, the transferor, who has had to answer a call or assessment, should be indemnified by the transferee. ${ }^{46}$ Thus, where the corporation is, or its creditors, are able to ascertain the identity of the real owner of the stock, a direct suit against such person seems proper not only under the reasonin the Bru case but also because it avoids litigation.

(b) After Recording of Transfer: Where there has been a bona fide transfer of shares and the transfer has been recorded, the courts are in complete harmony that the transferee is liable for further calls or assessments regardless of whether the suit is brought by the corporation ${ }^{\mathbf{4 7}}$ or creditors of the corporation. ${ }^{48}$ As was pointed out in Webster $v$. Upton, ${ }^{48}$ there is an implied promise, if not a direct one, on the part of the original purchaser of shares to pay an assessment or a balance due when called upon, and the transferee, upon coming into privity with the corporation through the transfer, must assume that same burden. ${ }^{50}$

(c) Lack of Knowledge of the Transferee: An important exception to the last rule stated exists where the transferee accepts shares without knowledge that it is subject to assessments or that the purchase price has not been fully

39. Middletown Bank y. Magill, 5 Conn. 28 (1823); In re People's Live Stock Ins. Co., 56 Minn. 180, 57 N. W. 468 (1894).

40. People's Home Savings Bank v. Stadtmuller, I50 Cal. I06, 88 Pac. 280 (I906); Topeka Mfg. Co. v. Hale, 39 Kan. 23, I7 Pac. 60I (1888) (suit by assignee of corporation). 4I. Marks \& McKey v. Brenner, 204 IIl. App. 366 (r9i7) ; Broderick v. Aaron (Kornberg), 268 N. Y. 260, 197 N. E. 274 (1935); Gordon v. Northern Trust Co., I2I Pa. Super. 79, 183 Atl. 352 (1936) (action by receiver).

42. 75 F. (2d) 729 '(C. C. A. 9th, 1935).

43. $75 \mathrm{~F}$ (2d) 729 , at 730 . See supra note 7.

44. Citing Johnson v. Moore, 31 Ariz. 137, 250 Pac. 995 (I926) (unrecorded shareholder who had paid assessment permitted to recover dividends not paid to him).

45. Accord: Ohio Valley Nat. Bank v. Hulitt, 204 U. S. I62 (1907) (pledged stock); Wright v. Keene, 82 Mont. 603,268 Pac. 545 (I928).

46. Supra note I3.

47. Hartford \& N. H. R. R. v. Boorman, I2 Conn. 530 (1838) ; Visalia \& Tulane R. R. v. Hyde, I1o Cal. 632, 43 Pac. Io (1895) ; Bend v. Susquehanna Bridge \& Bank Co., 6 Harris \& J. I28 (Md. I823).

48. Webster v. Upton, 9I U. S. 65 (1875) (suit by assignee in bankruptcy); Pullman v. Upton, 96 U. S. 328 (1877) (suit by assignee in bankruptcy); Crawford v. Swicord, I47 Ga. 548, 98 S. E. I025 (I918) ; Coleman v. Howe, I54 I11. 458, 39 N. E. 725 (I895); Edwards v. Schillinger, 245 Ill. 23I, 9I N. E. ro48 (rgIo) ; Sigua Iron Co. v. Brown, I7I N. Y. 488, 64 N. E. 194 (1902); Mountain Lake Land Co. v. Blair, Iog Va. 147, 63 S. E. 75 I (I909). 49. 91 U. S. 65 (1875).

50. 9 I U. S. at 69 . 
paid. In the leading case of Bryant $v$. Ehlen, ${ }^{51}$ where there was no indication on the certificates that the shares were not fully paid, the court points out that since the transferee had no notice of the unpaid purchase price, there clearly could be no implied promise to answer to calls. Bryant v. Ehlen is supported by the weight of authority no matter whether suit is brought by the corporation ${ }^{52}$ or creditors of the corporation..$^{53}$ This view is further supported by Section I5 of the UnIForm STOck Transfer ACT which prohibits any liens or restrictions upon shares unless such restrictions are printed on the certificate. $^{54}$ The avowed purpose of this provision is to make share certificates as much like negotiable instruments as is reasonably possible. ${ }^{55}$ Nevertheless, one state, California, has consistently held that a transferee takes shares subject to all liabilities which the transferor had, regardless to the former's knowledge. ${ }^{56}$ No cases have been found outside of California which support its view, and although the California rule tends to protect innocent creditors of the corporation, it has the greater disadvantage of hindering the transfer of shares.

(d) Liability of Transferee for Debts Incurred Prior to His Shareholdership: Occasionally, subsequent to the acquisition of the status of a shareholder, the transferee maintains that he should not be held liable for assessments or calls that are made to satisfy corporate debts which were incurred prior to his having become a shareholder. Little sympathy has been shown by the courts for this contention with the result that only one case has been found which protected a transferee in a suit for the unpaid purchase price of shares held by him, ${ }^{57}$ while the heavy weight of authority is to the effect that one who is a shareholder at the time of suit is liable regardless of when the debts accrued. ${ }^{.8}$ Having voluntarily joined the corporate enterprise, by acquiring shares with knowledge that they were subject to assessments or to calls for the balance of the purchase price, a shareholder should not be permitted to enjoy the benefits incidental to shareholdership without assuming liability for the coexistent burdens.

\section{Summary}

From the foregoing discussion, it is apparent that the respective liabilities of transferors and transferees of shares for calls and assessments have become rather clearly defined. Once there has been a recording of the transfer, the transferee is always liable while the transferor's responsibility is, in most instances, ended. In situations where no recording has taken place, neither the

5I. $59 \mathrm{Md}$. I ( 1882 ).

52. West Nashville Planing Mill Co. v. Nashville Sav. Bank, 86 Tenn. 252, 6 S. W. 340 (I888) (transferee was a pledgee).

53. French v. Harding, 235 Pa. 79, 83 Atl. 586 (I912) ; Blain v. Patterson, 62 S. D. 407, 253 N. W. 478 (1934).

54. 6 UNIFORM LAws ANN. (1922) 20. The act has been adopted in 24 states and Alaska. See 6 UnIForm Laws Ann. (Supp. I936) 5.

55. See commissioner's note to $\S 15$ of the UNIFORM STOCK Transfer Act, 6 UNIFORM Laws ANN. (I922) 20; United States Gypsum Co. v. Houston, 239 Mich. 249, 252; 214 N. W. 197,199 (1927).

56. Perkins v. Cowles, 157 Cal. 625, I08 Pac. 7II (I910); Geary St. P. \& O. Ry. v. Bradbury Estate Co., I79 Cal. 46, I75 Pac. 457 (I918). Although California has adopted the UNIFORM STOCK TRANSFER ACT, it has altered section 15 by making the information upon a share certificate that it is not fully paid permissive and within the discretion of the corporation, instead of mandatory: CAL. CIV. Cone (Deering, I93I) $\S 330.15$. This can probably be explained by the fact that, until recently, California did not recognize the general view that a shareholder's liability can be limited.

57. Chesley v. Pierce \& Sawyer, 32 N. H. 388 (1885).

58. Visalia \& Tulane R. R. v. Hyde, i io Cal. 632, 43 Pac. io (1895); Root v. Sinnock, I2o Ill. 350, II N. E. 339 (I887) ; Curtis v. Harlow, 53 Mass. 3 (I846); Ćleveland v. Burnham, 55 Wis. 598 , I3 N. W. 667 (1882). 
transferor nor the transferee is entirely safe from litigation. Nevertheless, there seems to have been little analysis on the part of the courts as to why recording should be all-important. In many cases, as, for example, a suit against an unrecorded transferee, there would seem to be no equitable reason to consider recording in determining the proper person to be liable. On the other hand, it cannot be denied that recording does serve as a concrete notification to all parties concerned of the change in shareholder membership. At all events, the importance of recording share transfers cannot be overemphasized inasmuch as it has been made the governing factor, the presence or absence of which most likely will determine upon whom shall fall the burden of answering subsequent calls or assessments.

$W . W . J r$.

\section{Election Disputes Within Trade Unions}

\section{Types and Significance of Disputes}

Labor's more spectacular battles may be those waged against employers, or, as of late, inter-union strife, but the pages of federal and state reports frequently contain accounts of litigation growing out of internal dissension within the union. The sharpness of the dispute is often surpassed in interest only by the vital import that this domestic combat contains for the individual laborer. His right to work may well be the issue. The facts that give rise to intra-union troubles follow no stereotype pattern. Variety is the rule rather than the exception. The disputes themselves may more easily be classified. They embrace disciplinary questions of fine, suspension, expulsion, ${ }^{1}$ problems of admission to membership, ${ }^{2}$ or of seniority rights, ${ }^{3}$ or allegations of improper use of union funds. ${ }^{4}$ Another large and important group relates to voting controversies. It is primarily with this group that this discussion deals. The issues here are neither of equal interest nor of equal significance, to union leaders, union members, or to the public. It may be that the only point that is involved is whether a procedural technicality was observed in the conducting of an election of an officer. Perhaps there is a dispute between $A$ and $B$ in which each contends that he has been chosen to fill an office of the union, ${ }^{5}$ with nothing more at stake than the private ambition of each. But the same set of facts may provide the battleground on which there is to be determined a fundamental principle of control. Thus if $A$ is the chosen leader of a local group which is asserting its right to autonomy, and $B$ is the representative of another group from the union hierarchy of councils, that which is really in issue is whether the democratic process of government shall prevail within the union. ${ }^{8}$ It may be that the conflict occurs not over the

I. For a discussion of disciplinary problems, see Steever, The Control of Labor Through Union Discipline (I931) I6 CoRN. L. Q. 212; Notes (I930) 30 CoL. L. REv. 847, (I917) I Mrnn. L. Rev. 513, (1936) 20 MINN. L. Rev. 657, (I934) I2 N. Y. U. L. Q. REv. 29I, (I935) 44 Yale L. J. 1446, (1936) 45 YALE L. J. I248.

2. See Note (1936) 20 Minn. L. Rev. 657, 66r; Wrightington, Unincorporated Associatrons and Business Trusts (2d ed. 1923) 297.

3. All the cases are reviewed in Christenson, Seniority Rights Under Labor Union Working Agreements (1937) II TEMr. L. Q. 355.

4. See Note (1936) 20 Minn. L. Rev. 657,665.

5. Farrell v. Cook, 58 Hun 603 , II N. Y. Supp. 326 (Sup. Ct. ISgo).

6. Malloy v. Carroll, 272 Mass. 524, I72 N. E. 790 (1930); Webster v. Rankins, 50 S. W. (2d) 746 (Mo. App. I932) ; Local No. 373 v. International Ass'n, I20 N. J. Eq. 220, I84 Atl. 53I (1936). 
result of any given vote, but over the right to participate in an election. ${ }^{7}$ Then the problem to be decided is whether an individual or a group may be disfranchised. A similar consideration is present when an individual or a group seeks either to force an election to be held that has been denied, ${ }^{8}$ or makes an effort to prevent the holding of an election which may adversely affect some interest.9 Methods by which such disputes are presented to be adjudicated also differ. The court may be asked to decide directly the disputed point. ${ }^{10}$ But if $\mathrm{A}$ brings an action to secure possession of property in the hands of $B, 11$ the ultimate right of possession depending on the validity or invalidity of an election, or if $A$ has been expelled and seeks reinstatement, alleging that the board which ousted him was not duly chosen, ${ }^{12}$ the issue is raised collaterally. It may be inquired of what concern it is to the courts in any event that disputes arise concerning elections, and why they should exercise jurisdiction at all. One answer is that the leadership within unions has been known in some instances to be less interested in the members than in its own welfare. In consequence there may well appear in those cases administration that is unenlightened and designed to further personal gain and ambition. Discrimination and a degree of corruption then become inevitable concomitants. ${ }^{13}$ Where such leadership exists, disciplinary weapons of fine, suspension, or expulsion become a potent means of controlling opposition. Moreover there has occasionally appeared a tendency, where such leadership exists, to prevent free expression of opinion and opposition. Penalties have been imposed where the offense was seemingly nothing more than free thought. ${ }^{14}$ This is probably explained by the history of trade unionism,

7. Cameron v. International Alliance, II8 N. J. Eq. II, I76 Atl. 692 (1935), aff'd in II9 N. J. Eq. 577, 183 Atl. 157 (1936), 45 Yale L. J. I494; Collins v. International Alliance, II9 N. J. Eq. 230,182 Atl. 37 (Ch. 1935); Bertucci v. United Cement Masons' Union, I39 Misc. 703, 249 N. Y. Supp. 635 (Sup. Ct. 193I).

8. Walsche v. Sherlock, I10 N. J. Eq. 223, I59 Atl. 66I (Ch. I932); Harris y. Geier, II2 N. J. Eq. 99, I64 Atl. 50 (Ch. 1932); Irwin v. Possehl, I43 Misc. 855, 257 N. Y. Supp. 1927).

9. McNichols v. International Typographical Union, 2I F. (2d) 497 (C. C. A. 7th,

Io. Carey v. International Brotherhood, I23 Misc. 680, 206 N. Y. Supp. 73 (Sup. Ct. r924); Bennett v. Kearns, 88 Atl. 806 (R. I. 1913); Amalgamated Society v. Jones, 29 T. L. R. 484 (K. B. I9I3). II. Chamberlain v. Lincoln, I29 Mass. 70 (1880) (lodge); Farrell v. Cook, 58 Hun. 603,
II N. Y. Supp. 326 (Sup. Ct. I890).

I2. Jose v. Savage, I23 Misc. 283 , 205 N. Y. Supp. 6 (Sup. Ct. I924); Maclean v. The Workers' Union, [1929] I Ch. 602; cf. Roberts v. Kennedy, 15 Del. Ch. 24, 140 Ati. 654 (Ch. 1925) (where $A$ as union president sued $B$ for breach of trust. $B$ 's defense was that $A$ was not president.).

I3. In Collins v. International Alliance, II9 N. J. Eq. 230, 238, 182 Atl. 37, 42 (Ch. 1935), it appeared that union members were forced to perform officers' jobs. Officers extorted money through control of jobs. There was also financial mismanagement. So also in Chalghian v. International Brotherhood, II4 N. J. Eq. 497, I69 At1. 327 (Ch. 1933), there was gross financial mismanagement. See Mintz, Trade Union Abuses (I932) 6 ST. JoHN's L. REv. 272; Note (1936) 20 MinN. L. REv. 657; N. Y. Times, Dec. 21, 1937, p. Io, col. r, where four labor leaders were indicted for extorting money from builders, and the indictment spoke of ". . the evil and damage done by these unprincipled racketeers whose dictatorship is robbing union labor of its right to work. . ."

I4. Jose v. Savage, I23 Misc. 283,205 N. Y. Supp. 6 (Sup. Ct. I924) (preferring charges against leaders); Spayd v. Ringing Rock Lodge, 270 Pa. 67, II 3 At1. 70 (I92I) (beneficial association) (petitioning a legislature); Abdon v. Wallace, 95 Ind. App. 604,165 N. E. 68 (I929) (testifying under oath to an opinion contrary to a position advocated by the union); Burke v. Monumental Div., 273 Fed. 707 (D. Md. Igrg), Hall v. Morrin, $293 \mathrm{~S}$. W. 435 (Mo. App. 1927) (instituting an action against union or officers); Riverside Lodge v. Amalgamated Ass'n, 13 F. Supp. 873 (W. D. Pa. 1935) (holding an unauthorized meeting); Koukly v. Canavan, I54 Misc. 343, 277 N. Y. Supp. 28 (Sup. Ct. I935) (taking a vote of members without authority to do so); ; Heasley v. Operative Plasterers, 324 Pa. 257, 188 At1. 206 (I936) (refusing to retract a letter criticizing the attitude of officers in regard to a 
evolving from the period when laborers' collective activity was illegal as a conspiracy and a restraint of trade, and unquestioning devotion to the cause was indispensable. ${ }^{15}$ That the reason no longer exists is apparent. ${ }^{16}$ Where these factors of unfortunate choice of leaders and suppression of honest opposition appear, the need for occasional exercise of jurisdiction by courts becomes discoverable. Whatever effective control the members are to retain over the officers can come only through the channel of free choice of leaders and uncontrolled and unhampered exercise of voting rights. Unless there is an adequate power that will accept jurisdiction in election controversies and resolve them in accordance with judicially determined standards, there may be little prospect that union members who are subjected to undesirable leadership will be able to interfere with the controlling group, or displace it. If leadership control of elections cannot be effectively contested, and if there is but a limited review of this type of dispute in the courts, it follows that in those cases where the leadership seeks improper power or gain, the economic existence of the members is largely out of their own hands.

\section{Limitations Upon Jurisdiction}

When a member of a union seeks the aid of a court in an issue that involves an election dispute, he is met at the outset by several common law principles that may be a barrier to the litigation. These doctrines existed before labor unions were recognized as lawful. They were customarily invoked when internal problems in voluntary non-profit associations found their way into court. ${ }^{17}$ One of the principles is to the effect that the constitution and by-laws of the union constitute a contract among the members. It follows that the plaintiff's path is a difficult one if he is unable to allege a breach of contract, in that the rules of the union were not complied with. If there has been no breach, courts are reluctant to exercise jurisdiction. The contract theory may be found in innumerable cases of labor union dissension that have been passed upon by the courts. ${ }^{18}$ An English court has stated that "A person . . . has ... no legal right of redress if he be expelled according to the rules, however unfair and unjust the rules or the action of the expelling tribunal may be ...." 19 Not all the American decisions have been either so utterly unrealistic or so devoid of hope for the union member. Nor has the contract theory gone without criticism. It has been subjected to penetrating attack. ${ }^{20}$ But in general the attention of the court will be directed to the inquiry whether the rules have been observed.

strike) ; Love v. Grand International Div., 139 Ark. 375, 215 S. W. 602 (1919) (issuing a circular in relation to the business of the brotherhood) ; Neal v. Hutcheson, I60 N. Y. Supp. 1007 (Sup. Ct. Ig16) (refusing to accept a strike settlement).

I5. Groat, Organized Labor in America (1926) I7, i8. See Frankfurter aNd GREENE, THE LABOR INJUNCTION (I930) 2 et seq., for an account of the early application of the doctrines of conspiracy and restraint of trade to the labor union.

16. Commonwealth v. Hunt, 4 Met. III (Mass. I842), rejected the idea of criminal conspiracy. Validity of union: Hitchman Coal \& Coke Co. v. Mitchell, 245 U. S. 229 (IgI7); Pickett v. Walsh, 192 Mass. 572,78 N. E. 753 (1906).

17. Low v. Harris, go F. (2d) 783,785 (C. C. A. 7th, I937) C Carey v. International Brotherhood, I23 Misc. 680, 687, 206 N. Y. Supp. 73, 83 (I924); Williams v. District Executive Bd., I Pa. D. \& C. 3I, 34 (I92I).

I8. Walsche v. Sherlock, IIo N. J. Eq. 223, 227, I59 Atl. 66r, 663 (Ch. I932) ; Carey v. International Brotherhood, I23 Misc. 680, 687, 206 N. Y. Supp. 73, 83 (Sup. Ct. I924); Cox v. United Brotherhood, 69 P. (2d) I48, I50 (Wash. 1937).

Ig. Maclean v. The Workers' Union, [I929] I Ch. 602, 624. But in Burn v. National Amalgamated Labourer's Union, [1920] 2 Ch. 364, 374, it was stated that even if the rules authorized removal of an officer without a hearing, such rule would be invalid as opposed to natural justice.

20. Chafee, The Internal Affairs of Associations Not for Profit (1930) 43 Harv. L. REv. 993, I00I-1007. This is one of the best discussions that has appeared on the nature of the voluntary association. 
Another rule usually stated to be applicable in cases arising from within voluntary associations is that where the association itself contains adequate appellate machinery, the courts will not interfere until internal remedies have been exhausted.21 This is, then, a second problem that confronts the union member when he asks the court to act in reference to an election controversy. The principle is in reality only a phase of the concept that the rules of the union constitute a contract among the members. It is usually referred to in judicial opinion, however, as a separate basis for a consideration of whether or not to exercise jurisdiction. The appellate machinery within the association is invariably provided for by the constitution or by-laws. It may include a long drawn out method of appeal through a series of tribunals requiring long intervals of delay. Final appeal is apparently taken in the usual situation to the convention that meets annually or less frequently.

Apart from the question of the contract that is said to exist in the union rules, and the requirement that remedies within the union shall have been exhausted, the ubiquitous "property right" so long searched for in courts of equity is treated as a condition precedent to the exercise of jurisdiction in this type of dispute. ${ }^{22}$ Like the contract theory, the property right theory has been criticized as the basis for intervention in union disputes. ${ }^{23}$ It is suggested that the real basis for protection of rights is the relationship that arises from membership. ${ }^{24}$ But the cases abound with statements regarding property rights. That has long been true where litigation results from a controversy within any type of voluntary association. But it is not, of course, an exclusive characteristic of actions involving internal problems in associations, but rather the same idea that has permeatel equity jurisdiction in general.

The wisdom of such judicial formula in these cases is open to question. When a court is asked to pass upon the merits of a union controversy, one may ask whether there is any justification for quoting the same rule of law and citing the same group of authorities to be relied upon in a controversy within a fraternity, or a lodge, or a social club, merely because all are regarded as voluntary associations not for profit. The distinction is articulate in but few cases. ${ }^{25}$

\section{Policies Governing the Exercise of Jurisdiction}

Consideration of the principles that are generally thought to govern the exercise of jurisdiction, in their application by the courts, will be made in inverse

2r. Hickey v. Baine, 195 Mass. 446, 8I N. E. 201 (I907) ; Crisler v. Crum, II5 Neb. 375 213 N. W. 366 (I927) (seniority dispute) ; Bertucci v. United Cement Masons' Union, I39 Misc. 703, 249 N. Y. Supp. 635 (Sup. Ct. I93I) ; Fraser v. Buck, 234 S. W. 679 (Tex. Civ. App. I92I) (benevolent society); OAKES, ORganized Labor aNd IndUStrial Conflicts (I927) 94 .

22. Barbrick v. Huddell, 245 Mass. 428, I39 N. E. 629 (1923); Reichert v. United Brotherhood, I4 N. J. Misc. I06, I83 Atl. 728 (Ch. 1936) ; Heasley v. Operative Plasterers, $324 \mathrm{~Pa} .257$, I88 Atl. 206 (1936) ; see Franklin v. Pennsylvania-Reading Seashore Lines, I22 N. J. Eq. 205, I93 Atl. 712, 7I8 (Ch. I937); OAKES, op. cit. supra note 2I, at 35.

23. Chafee, supra note 20, at 999-100I.

24. Id. at I007; see also case note on Cameron v. International Alliance, IIg N. J. Eq. 577, I83 Atl. I57 (I936), 45 YALE L. J. I494.

25. “. . . autonomous possession and exercise of rights and powers during a period of 25 years . . by a particular class of the membership, can hardly be characterized as a purely internal affair of a voluntary association." Howard v. Weissmann, 3I F. (2d) 689, 694 (C. C. A. 7th, I929). "Something more than mere membership in a voluntary association is embraced in this case. . . . Their right to labor is property. . . . The right to make it available is next in importance to the rights of life and liberty." Barbrick v. Huddell, 245 Mass. 428, 435, I39 N. E. 629, 631 (I923). "The exact and prompt solution of such disputes [in mutual benefit society] are of small importance either to the state or to the litigants compared to the major controversies that sometimes develop within trade unions. Harris v. Geier, II2 N. J. Eq. 99, I06, I64 At1. 50, 53 (Ch. 1932). 
order. Plaintiff is called upon to demonstrate to the satisfaction of the court that he has a property right at stake about which he wishes the court to take some action. A study of the cases involving labor unions suggests that a property right is often found. In fact, it appears that in few cases of union disputes has the court rejected consideration of the merits of the case on the ground that no property right was involved. At least insofar as the question of finding a property right is involved, it does not appear to matter whether the particular issue sought to be litigated is an election dispute, or a disciplinary problem, or any of the other forms of litigation that may arise from the union's internal conduct. If the plaintiff's claim is meritorious, the court can and does find, and perfectly legitimately, a property right. Thus property rights have been found to exist in benefits paid by the union, ${ }^{26}$ in the right to work, ${ }^{27}$ in the right to vote, ${ }^{28}$ in the selection of a representative. ${ }^{29}$ If the union member has any real grievance, the court is unlikely to reject a review of the case in the absence of a traditional property right. If the courts continue to require the presence of a property right before reviewing the substance of an election dispute, there is no good reason why a property right should not always be found. Since union membership often controls the ability to follow a given occupation, and since there are usually certain benefits attached to membership, such as strike or unemployment or death benefits, the right to a free and unhampered voice in internal government can itself be labelled a property right. Standing alone and with no other circumstances in the picture, it may not bear a very close resemblance to the traditional concept of a property right. But if it is considered in conjunction with the surrounding facts, it is in reality the right to share in control of the union organization which may well be the most important single factor in the economic destiny of the individual member.

The generally stated rule that a union member who seeks the aid of the court must first exhaust his remedies as provided within the association itself, if applied literally, would constitute a very serious problem to a member who has in fact been unfairly treated. If, for instance, a local union were wholly deprived of the right to self-organization, and elections forbidden, by the parent organization, which put in its own officers to dominate all activities of the local, whether or not in violation of the union constitution; and if, as in one instance, the national convention were held only once in four years, ${ }^{30}$ nearly four years might elapse before appeal could be taken to the convention. But as might be expected, the rule is not applied literally, and as in the principle requiring a property right, there appears to be in effect considerable departure from the common law doctrines applicable to voluntary associations. This is true whether the litigation involves an election dispute or some other type of problem. So many exceptions have been engrafted upon the rule that it appears to apply in only a minority of cases. In a majority of cases of election disputes surveyed, the necessity of exhaustion of internal remedy was dispensed with. The reasons given are that it is not necessary to appeal to a union tribunal if there would be great delay, ${ }^{31}$ or if the action

26. Howard v. Weissmann, 31 F. (2d) 689, 693 (C. C. A. 7th, 1929).

27. Walsche v. Sherlock, I10 N. J. Eq. 223, 249, I59 Atl. 66I, 672 (Ch. 1932).

28. Osborne v. Amalgamated Society, [IgII] I Ch. 540, 567 .

29. Myers v. Louisiana \& A. Ry., 7 F. Supp. 92, 97 (W. D. La. 1933). This was an action by the union to restrain the railroad company from interfering in the selection of officers. System Federation No. 40 v. Virginian Ry., II F. Supp. 62I (E. D. Va. 1935),
aff'd, 84 F. (2d) 64I (C. C. A. 4th, I936), aff'd, 300 U. S. 5I5 (I937), was also an action to restrain outside interference in a union election. Here too, at 633 , the court found a property
right in the right of self-organization and representation.

30. Reichert v. United Brotherhood, I4 N. J. Misc. Io6, I83 Atl. 728 (Ch. 1936). 3I. Ibid., the disputed question being one of merger; Bailey Montgomery, I77 App. Div.
777, I65 N. Y. Supp. I 59 (Ist Dep't, I9I7) (lodge). 
appealed from is contrary to public policy and void,,$^{32}$ or if property rights are involved, ${ }^{33}$ or if the action appealed from was in excess of authority, ${ }^{34}$ or if damages are sought, ${ }^{35}$ or if an appeal would plainly be futile and vain. ${ }^{\mathbf{3}}$ These phrases are elastic. They suggest that in any case where to appeal to the union tribunal would be unduly inconvenient, or cause needless hardship, an exception will be found. No loss would be felt if the rule were dispensed with entirely, and the fact of whether or not the complainant had exhausted all possible remedies were regarded as but one factor in the court's determination of whether it would exercise jurisdiction. Such appears to be the rule in effect in the decisions cited above, though not articulate.

In the application of the principle that the ruies of the union constitute a contract among the members, the typical attitude of the courts is to inquire what are the rules as provided by constitution and by-laws, and whether they have been observed. Compliance will be required if they have not. ${ }^{37}$ In the law relating to voluntary associations not for profit, one rule is that the majority governs in any vote that may be regularly taken. ${ }^{38}$ The rule is equally applicable within trade unions. One type of situation has arisen in two recent cases that presents another rule. A majority of the members of the union, purporting to act for the entire local, voted to dissolve the old union and to set up a new one. In one case the action sought to effect a transfer of funds from the old local to the new group. ${ }^{39}$ In the other, there was a bill to restrain the officers of the old local from continuing to act as representatives of the union. ${ }^{40}$ The result was the same in each instance. The majority was held to have seceded and to be unable to control the union property, which remained in control of the remaining minority. Thus there is this limitation on a rule of majority control.

But illustrative of the typical response to election disputes is a case in which, in an election of national officers, votes of certain locals were rejected because

32. Cameron v. International Alliance, II8 N. J. Eq. II, I76 Atl. 692 (I935).

33. Harris v. Geier, II2 N. J. Eq. 99, I64 Atl. 50 (Ch. I932); Lo Bianco v. Cushing, II7 N. J. Eq. 593, I77 Atl. I02 (Ch. 1935) (expulsion).

34. Local No. 7 v. Bowen, 278 Fed. 27 I (S. D. Tex. 1922); Webster v. Rankins, 50 S. W. (2d) 746 (Mo. App. 1932) ; Irwin v. Possehl, I43 Misc. 855, 257 N. Y. Supp. 597 (Sup. Ct. 1932). Contra: Bertucci v. United Cement Masons' Union, I39 Misc. 703, 249 N. Y. Supp. 635 (Sup. Ct. I93I). sion).

35. Grand International Brotherhood v. Green, 210 Ala. 496, 98 So. 569 (I923) (expul-

36. Walsche v. Sherlock, I Io N. J. Eq. 223, I59 Atl. 66I (Ch. I932); Local No. II v. McKee, II4 N. J. Eq. 555, I69 Atl. 35I (Ch. I933); Neal v. Hutcheson, I60 N. Y. Supp. 1007 (Sup. Ct. Igr6).

37. Dahl v. Palache, 68 Cal. 248, 9 Pac. 94 (I885) (church, notice not given); Harris v. Geier, II2 N. J. Eq. 99, I64 Atl. 50 (Ch. 1932) (prevention of meetings and election); Goller v. Strubenhaus, 77 Misc. 29, I34 N. Y. Supp. I043 (Sup. Ct. 1912) (benevolent society, notice not given) ; Bailey v. Montgomery, I77 Ap. Div. 777, 165 N. Y. Supp. I59 (Ist Dep't, I9I7) (lodge, meeting at wrong place); Williams v. District Executive Bd., I Pa. D. \& C. 3I (I92I) (nomination dispute).

38. Goesele v. Bimeler, I4 How. 589 (U. S. 1852) (society); Tucker v. Paulk, 148 Ga. 228, 96 S. E. 339 (IgI8) (church) ; Stryjewski v. Panfil, 269 Pa. 568, II2 Atl. 764 (Ig2I) (church). System Federation No. 40 v. Virginian Ry., II F. Supp. 621 (E. D. Va. I935). aff'd, 84 F. (2d) 64 I (C. C. A. 4th, 1936), aff'd, 300 U. S. 515 (1937), and Association of Clerical Employees v. Brotherhood, 85 F. (2d) I52 (C. C. A. 7th, I936) were cases interpreting the Railway Labor Act, 44 STAT. 577 (I926), amended by 48 STAT. Ir85 (I934), 45 U. S. C. A. § I5I (Supp. I937). In both cases it was held that the majority of a craft meant only that a majority must vote, and that a majority of those voting could determine in a choice between a company union and the A. F. of L.

39. Low v. Harris, 90 F. (2d) 783 (C. C. A. $7^{\text {th }}$ 1937).

40. Martin v. Smith, 286 Mass. 227, I90 N. E. II3 (1934). In Flaherty v. Portland Longshoreman's Benevolent Society, 99 Me. 253, 59 Atl. 58 (I904), a minority of the union prevented the majority from acting on a resolution authorizing expenses beyond the by-laws, though the by-laws could have been altered by majority vote. 
the rules had not been complied with. The result was to elect B instead of A. The errors were that the votes had not all been taken in one day, or that they were taken before the appointed day, or that there were not enough supervisors, and in one case that a charter fee had not been paid. The lapses were due to the neglect of local officials. The court held that where the rules of the union covered the situation it would not interfere, unless public policy were involved. ${ }^{41}$ Here it did not think such an element was present. The potentialities of such a rule within the union are apparent. Officers, through the simple device of slight technical errors, are enabled to disfranchise the entire membership of a given local.

Courts will ordinarily interfere in the internal management of the union either to prevent or to undo conduct by the organization that is either contrary to the rules or else not specifically permitted thereunder, viewing them as parts of a contract that should be adhered to. Frequent cases illustrate this point. Thus, where a rule was passed that anyone "who worked against the interest of local 570 " should lose, for ten years, the right to a voice or vote or to hold office, the court prevented enforcement of the rule on the ground that there was no authority that permitted the union to pass such a rule. ${ }^{42}$ In another case where the county tribunal took over the management of the local union, and refused to allow an election to be held, the court granted a decree to restore the autonomy of the local, on the ground that there was no authority for such action.43 There has been a group of cases involving the same general issue, where the complainant or complainants sought the right to participate freely in an election, or the right to have an election held where it had been denied.4 A slight variation of the facts occurred in another instance where national officers refused to allow a local union to hold any elections. The local proceeded nevertheless to hold an election, whereupon the national officers endeavored to cause local members to lose their employment. An injunction was granted restraining the prevention of the election, as well as the other unauthorized conduct. ${ }^{45}$ The conclusions that may be drawn from cases of this type are that the courts will exercise jurisdiction to compel compliance with the union rules where they have been disregarded; and, in another phase of the same principle, that where there is conduct which may not violate any given rule but which is not specifically authorized, the conduct may be restrained or undone, if it is in plain disregard of some substantial right.

There is another category of cases in which the plaintiff's grievance does not rest upon a violation of constitution or by-laws of the union, or upon an alleged action that is not specifically authorized, but rather upon the contention that conduct that is apparently permitted by the union rules is nevertheless so unfair that the rules should be disregarded. There are not many cases involving an election dispute where such question has arisen, though there are many where the contention might well have been made to the court. It might be pointed out that such argument has frequently been sustained by courts with reference to other types of litigation that have arisen from union difficulties. Thus 1924).

4I. Carey v. International Brotherhood, I23 Misc. 680, 206 N. Y. Supp. 73 (Sup. Ct.

42. Bertucci v. United Cement Masons' Union, 139 Misc. 703, 249 N. Y. Supp. 635 (Sup. Ct. I93I).

43. Harris v. Geier, II2 N. J. Eq. 99, I64 At1. 50 (Ch. I932).

44. Koukly v. Canavan, I54 Misc. 343, 277 N. Y. Supp. 28 (Sup. Ct. I935); Local No. II v. McKee, Ir4 N. J. Eq. 555, I69 Atl. 351 (Ch. 1933); Local No. 373 v. International Association, I20 N. J. Eq. 220, I84 Atl. 53I (I936).

45. Webster v. Rankins, 50 S. W. (2d) 746 (Mo. App. 1932). 
courts have held the rules requiring a member to have a permit to work, ${ }^{46}$ or depriving a member of the right to testify under oath, ${ }^{47}$ or denying the right of free speech, ${ }^{48}$ or forbidding petition to the legislature, ${ }^{49}$ or requiring relinquishment of constitutional rights as a condition of membership, ${ }^{50}$ will be set aside. The theory of such decisions is that the rule is so oppressive and unjust that the contract is against public policy. However, there are several cases where a similar result was reached in which the issue was either solely or at least partly concerned with an election controversy. In one interesting case, the international union, acting in accordance with its constitution, amended the constitution to eliminate an allied district union and make the locals comprising the district directly subordinate to the international. The effect was to destroy a 25 -year autonomy of the local unions. The court enjoined the carrying out of the amendment, declaring that such autonomy "by a particular class of the membership can hardly be characterized as a purely internal affair of a voluntary association." ${ }^{51}$ The result is simply that the court set aside the constitution of the union in order to protect the voting rights of a group. In other litigation involving the same parties, substantially the same result was reached under a different name. There the constitution directed the executive committee to submit amendments to the local unions on petition of 150 locals. There was a proper petition for an amendment aimed at depriving the plaintiff local of voting strength in the national organization. The executive committee declined to act, whereupon the president prepared to submit the amendment. The court held that he could not do this, that the committee as a whole had to act. ${ }^{52}$ Since it was plainly competent for the court to declare that the submission of the amendment was obligatory upon the committee, and hence that if the committee refused to act the president might act alone, the decision seems an evident matter of construing the union constitution to protect the voting rights of a minority. It is true that the court did not here hold that the constitution itself was unenforceable, but it so strictly construed the provision in question that it amounted to almost the same thing.

In two other cases the action was brought against a common defendant by separate plaintiffs. In both there were a series of particularly undesirable practices by union leaders. In the first case, the plaintiffs were by the rules of the union deprived of any voice whatsoever in union affairs. They petitioned to have the constitution and the by-laws annulled. The court set aside the entire arrangement, and accorded the plaintiffs a complete voice in determination of union affairs. ${ }^{53}$ In the second case, no annual elections had taken place for ro years, and certain officers remained in control through repressive practices. Here also the court restored to the plaintiffs the right to self-government and free elections of their own representatives. ${ }^{54}$

46. Walsche v. Sherlock, I Io N. J. Eq. 223, I59 At1. 66r (Ch. I932).

47. Abdon v. Wallace, 95 Ind. App. 604, I65 N. E. 68 (I929).

48. Eschman v. Huebner, 226 III. App. 537 (Ig22) ; Jose v. Savage, I23 Misc. 283, 205 N. Y. Supp. 6 (Sup. Ct. I924).

49. Spayd v. Ringing Rock Lodge, 270 Pa. 67, II3 Atl. 70 (Ig2r).

50. Cameron v. International Alliance, II 8 N. J. Eq. II, 23, I76 Atl. 692, 698 (1935) (holding that a union member may not be deprived of the "free use of his hands", and that one may not "barter away . . . freedom".

51. Howard v. Weissmann, 3x F. (2d) 689, 694 (C. C. A. 7th, 1929). 1927).

52. McNichols v. International Typographical Union, 2I F. (2d) 497 (C. C. A. 7th,

53. Cameron v. International Alliance, Ir8 N. J. Eq. I I, I76 Atl. 692 (Ch. I935).

54. Collins v. International Alliance, IIg N. J. Eq. 230, I82 Atl. 37 (Ch. I935). 
In another related case, a local union was entirely deprived of the right to hold elections, but was controlled by appointed officers. The court restrained the appointees from acting as officers, and decreed that the local hold its own election. It is true that the basis of the decision was that the constitution of the union had been violated. But the language plainly implied that if the rules had purported to permit this type of conduct, relief would nevertheless have been granted. It stated that "The constitution and laws of every labor organization are to be judged and construed in this State and country according to well-conceived ideals and principles of law ordained by a democratic people proud of their heritage and jealous of the protection of their rights of equal opportunity, of voice in the selection of local and general officials . . . "55

There is, therefore, in addition to the list of cases where the courts have disregarded the rules of the union in other controversies, a not inconspicuous group where constitution or by-laws have been similarly disregarded in election disputes. Here the question has been not what the rules were, but whether the rules were not oppressive. In these cases, although the defendants endeavored to block action with all of the traditional objections to exercise of jurisdiction by the court, the courts found the contract theory no obstacle whatsoever. A property right was easily discoverable. The doctrine of exhaustion of remedy within the union vanished before the urgent necessity of the facts.

\section{Conclusion}

That only a small minority of the cases of misuse of power ever come before the courts is the strong probability. The processes of litigation are costly and slow; fear of reprisals may exist. Added to this is what has been described as a distrust for legal processes on the part of workers. ${ }^{56}$ Ordinarily the problem of interference in union affairs presents a conflict of interests. On the one hand there is the feeling that the "rights of private government" 57 should not be disturbed. Opposed to this is the degree of hardship that will be inflicted upon the member by non-intervention where it is alleged that biased internal government necessitates an external adjudication. There is frequently a feeling that the group will be the most helpful if it is allowed to work out its own lines of development; that legal supervision may do more harm than good. Courts are not qualified to prescribe details of government for the internal affairs of associations. ${ }^{58}$ But in this particular problem of elections and controversies arising in connection with them, certain simple fundamentals could be regarded as principles by which unions were bound without depriving them of any legitimate right of autonomy. The union members should have the right to have elections as provided by the rules, or if they are not provided for by the rules, to have them regardless, with the right to compel them in court without fear of penalty. There should also be the right to participate in such elections, with resort to the courts to gain the right if denied. There should be the further right that one may not be disfranchised either by technicalities or by the error of others. There can be no objection to judicial compulsion of stringent safeguards against coercion or fraud. None of these rights should be able to be restricted in any case by constitution or by-laws of the union. Nor should penalties be permitted in any case for enforcing any of such rights. Courts could well take jurisdiction in any action where the complaint established a prima facie case of disregard of these rights, regardless of exhaustion of remedy within the union, or of the contract

55. Irwin v. Possehl, I43 Misc. 855, 858, 277 N. Y. Supp. 597, 60I (Sup. Ct. 1932).

56. Frankfurter and Greene, op. cit. silpra note 15 , at $13 \mathrm{I}$.

57. Amalgamated Society v. Jones, 29 T. L. R. 484,485 (K. B. 19I3).

58. Chafee, supra note 20 , at 1020 et seq. 
theory, or of the existence of property rights. It is time for complete recognition of the undoubted differences between the social club and those labor unions which have an army of members, large resources and power, importance to the public, economic significance, social significance, and political influence. The chief similarity between social clubs and such unions is that both organizations have always been given the same name--voluntary non-profit associations. Complete recognition of these distinctions would in no way interfere with the internal management or discipline that is needed within the union. The only thing sought is a responsive management. It is not suggested that a more sympathetic reaction by courts to election disputes within the union is a panacea for all intraorganization problems. The needs of any situation must rest upon a consideration of all its incidents. But a more ready willingness to intervene would provide a more satisfactory basis for solving many of the problems which have heretofore arisen.

\author{
C. E. H.
}

